\title{
WHAT'S CRITICAL ABOUT CRITICAL PHENOMENOLOGY?
}

\author{
GAYLE SALAMON \\ Princeton University
}

"Philosophy is everywhere, even in the 'facts,' and it nowhere has a private realm which shelters it from life's contagion."

Maurice Merleau-Ponty, Signs

\begin{abstract}
"The problem that I study in Visible and Invisible is the same as that of dialectics and Marxism. It is the problem of openness." Maurice Merleau-Ponty, Unpublished Note*
\end{abstract}

Several decades ago, Donn Welton and Hugh Silverman published Critical and Dialectical Phenomenology (1987), a volume of collected papers from the annual meetings of the Society for Phenomenology and Existential Philosophy in 1984 and 1985. The term "critical phenomenology" appears once in the book, and does not serve as the name of an altogether new kind of phenomenology so much as it offers adjectival modification of the old kind; Welton distinguishes between "classical" phenomenology, and phenomenology that is "more dialectical and critical" (xv). ${ }^{1}$ Critical phenomenology, then, or at least "a more dialectical and critical phenomenology," names something that was being practiced at SPEP in the 1980s: a philosophy that understood itself to be rooted in the classical phenomenological tradition at the same time as it somehow moved beyond those boundaries in terms of content, method, or discipline.

\footnotetext{
* I am grateful to David Morris for sharing this quotation and relating some of its attributional history. Morris cited it in his paper "Merleau-Ponty and Mexica Ontology: Time as Templacement," which he delivered at the 2017 Merleau-Ponty Circle in Albuquerque, NM. Renaud Barbaras transcribed many of Merleau-Ponty's notes from the period of time Merleau-Ponty was working on The Visible and the Invisible. Barbaras's student Franck Robert filled in and revised the transcription, which was an appendix to Barbaras's thesis. That thesis emerged as a book, Phénoménologie et Ontologie, but without the transcribed appendix. The version quoted here is based on a review and corrections of a selection of these notes by David Morris with the assistance of Juliette Corsy. The note is on p. 226 of Bibliothèque Nationale de France VIII.2 of Merleau-Ponty's notes located between two other unpublished notes dated 1959. It is also discussed by Mariana Larison in L'Etre en forme: Dialectique et phénoménologie dans la dernière philosophie de Merleau-Ponty (2016, 50).

${ }^{1}$ Welton characterizes Thomas Busch's contribution to the volume as "dialectical and critical phenomenology," in which Busch describes Sartre's move away from the emphasis on "unfettered freedom" in Being and Nothingness toward an interest in "the problem of ambiguity and conditioned existence" (1987, xv) in The Critique of Dialectical Reason. However, he also uses the term to name the collective work of the volume itself. The full sentence reads: "In many respects Thomas Busch finds in Sartre that same turn from a classical to a more dialectical and critical phenomenology that is at least adumbrated by all the authors in this volume" (xv).
} 
Other than that volume, there had been little that travels under the name of "critical phenomenology" within Continental philosophy until recently, with Lisa Guenther's Solitary Confinement: Social Death and its Afterlives in 2013 and Michael Marder's Phenomena-Critique-Logos: the Project of Critical Phenomenology in $2014 .^{2}$ In framing the project of critical phenomenology, Guenther defines it thusly:

By critical phenomenology I mean a method that is rooted in first-person accounts of experience but also critical of classical phenomenology's claim that the first-person singular is absolutely prior to intersubjectivity and to the complex textures of social life. The critical edge of this approach emerges through an engagement with the work of Frantz Fanon, Maurice Merleau-Ponty, and Emmanuel Levinas [. . .] I have sought to develop a method of critical phenomenology that both continues the phenomenological tradition of taking first-person experience as the starting point for philosophical reflection and also resists the tendency of phenomenologists to privilege transcendental subjectivity over transcendental intersubjectivity. (2013, xiii, xv)

For Guenther, an emphasis on intersubjectivity is what makes phenomenology critical. She utilizes classical phenomenology's advocacy of a first-person perspective at the same time as she resists the kind of transcendental idealism that would fix subjectivity into an individual and atomized subject, a singular subject surrounded by a world that it has constituted. This is a common critique of phenomenology: that its methods are insufficient for describing the relation of self to world, despite having this as its explicit goal. Phenomenology risks becoming a method whereby the world is collapsed back into consciousness (the charge of solipsism frequently leveled against Husserl) or of articulating a relation between self and world in which the two are indistinguishable, with the effect that the world turns out also to be self (a frequent critique of Merleau-Ponty's work). ${ }^{3}$ Some of Merleau-Ponty's own formulations can easily confirm such readings, such as his pronouncement in Phenomenology of Perception (2012) that "I am the absolute source" [je suis la source absolue] (xxii). He attempts there to describe a realignment of knowledge that might unseat the dominion of science and objective

\footnotetext{
${ }^{2}$ The sole exception that I can find is Max Velmans's "Heterophenomenology versus Critical Phenomenology." Velmans is a psychologist who advances critical phenomenology as a philosophy of mind, contra Daniel Dennett, "in which first- and third-person accounts of the mind are treated as being complementary and mutually irreducible" (2007, 227). Guenther's project is more concerned with offering a critical phenomenology of the effects of solitary confinement, while Marder is reflecting on the category of phenomenology itself, which he understands to be necessarily critical in that it reflexively raises the question of its own meaning. Marder suggests that "critique is the name for the relation between phenomena and logos" $(2014,2)$ which is "not superadded to but rather is endemic to phenomenology" (10).

${ }^{3}$ See Merleau-Ponty's "The Philosopher and His Shadow," and the short, final chapter of The Visible and the Invisible, "Preobjective Being, The Solipsist World." Husserl's own references to solipsism and the "solipsistic reduction," particularly in the fifth Cartesian meditation, would seem to confirm such worries. David Carr, however, suggests that Husserl uses solipsism in an experimental way in order to acknowledge the other even though I have no access to his or her experience. See: Carr, "The 'Fifth Meditation' and Husserl's Cartesianism"; Irigaray's discussion of Merleau-Ponty's "labyrinthine solipsism" in "The Invisible of the Flesh" (1993, 157); Merleau-Ponty's own comments on the untenability of the phenomenology of the subject in The Visible and the Invisible, in which he moves away from the philosophy of consciousness that characterized Phenomenology of Perception toward a philosophy of Being.
} 
perspective, but appears to replace it with a transcendental subject from whom everything emerges, inviting the charge, advanced by Levinas among others, of a subjectivism that cannot see otherness. Moving as it does between idealism and realism, Merleau-Ponty's work in the Phenomenology sought to find a way out of the snare of dualistic thinking in which so much of Western philosophy has found itself tangled. In his own assessment, he was not quite able to free himself from the dualism of subject/ object relations in Phenomenology of Perception, and his late work tried to radically reconfigure that attempt.

Levinas was foremost among those who challenged Merleau-Ponty's philosophy on the grounds that it fails to engage alterity, that it is not responsive to the otherness of the other, that it advances a perceiving subject who in looking toward the world finds only reflections of itself. Scott Marratto has recently argued, contra Levinas's critique that otherness is subsumed into sameness within Merleau-Ponty's theorizations of vision, that Merleau-Ponty's accounts of expression and vision "establish, on the one hand, the possibility of encountering otherness, and on the other hand, the possibility of recognizing the genuine alterity of the other" (2017, 243; italics in original). There is an openness at the heart of being, in Merleau-Ponty's words, and that openness rests on a prior relation to alterity. In the preface to Phenomenology of Perception, Merleau-Ponty's characterizations of method are a call for philosophy to turn back on itself: a turning back in which it interrogates itself. Yet this turning is somehow not the same as reflective analysis. This turning back allows us to see the ways in which human beings are subjects "destined to the world," in Merleau-Ponty's words (2012, xxiv); the world and those who inhabit it are opaque to reflective analysis, transformed into a "problem" by the cogito, but are precisely that which is disclosed by the phenomenological method, which he describes as the means by which we can arrive to, rather than shut out, the world:

Because we are through and through related to the world, the only way for us to catch sight of ourselves is by suspending this movement, by refusing to be complicit with it (or as Husserl often says, to see it ohne mitzumachen [without taking part]), or again, to put it out of play. This is not because we renounce the certainties of common sense and of the natural attitude - on the contrary, these are the constant theme of philosophy - but rather because, precisely as the presuppositions of every thought, they are "taken for granted" and they pass by unnoticed, and because we must abstain from them for a moment in order to awaken them and to make them appear. Perhaps the best formulation of the reduction is the one offered by Husserl's assistant Eugen Fink when he spoke of a "wonder" before the world. Reflection does not withdraw from the world toward the unity of consciousness as the foundation of the world; rather, it steps back in order to see transcendences spring forth and it loosens the intentional threads that connect us to the world in order to make them appear; it alone is conscious of the world because it reveals the world as strange and paradoxical. (xxvii)

Here, "reflection" is what lets us feel the grip our certainties and presuppositions have on our perception of the world, and when we notice but do not engage with those certain- 
ties, the world itself is allowed to emerge around us. What is revealed by the reduction as Merleau-Ponty conceives it is not a knowledge of essences, not the revelation of transcendental structure. While phenomenology is concerned with both essences and transcendental structures, the true purpose of our engagement with them for Merleau-Ponty is not system-building but an instrumental way into the world in which we are already dissolved. What results is not a certainty, but a rupture, a making-strange of the world, one which "can teach us nothing except the unmotivated springing forth of the world" (xxvii). The world does not dissipate or disappear as the intentional threads that bind us to it slacken, rather, we feel it newly "springing forth" as our constituting consciousness is replaced with receptive being. Our stance of certainty is transformed into one of wonder, and our relation to the world is one of felt openness. ${ }^{4}$ Rupture describes our relation to the world once our structures of knowing are held in abeyance, and also our relation to our habits of perception which are similarly dis-oriented once we step back from the natural attitude.

Very soon after warning us about the dangers of reflective analysis and his vow to eschew explanation, Merleau-Ponty makes this move at the end of the preface, fundamentally recasting philosophy as reflective and reflexive: "It will be necessary that philosophy direct toward itself the very same interrogation that it directs toward all forms of knowledge. It will thus be indefinitely doubled; it will be, as Husserl says, an infinite dialogue or meditation" (2012, xxxv). Thus the project of phenomenology is an open and unfinished one, whose goal is also an opening. "Man" is not at the center of the world like the spadix in the lily. He is instead inevitably open to it because he is of a piece with it, comprised of it, and the value of the reduction is that it might allow him to see the world in its springing forth, not merely in its conformation with his knowledge of it. This turning-back is the opposite of mastery, and it brings not verification but strangeness. The phenomenologist does not find what she was already seeking. She feels herself folded into the undifferentiated presence of the world once she suddenly cannot recognize it.

In "The Masked Philosopher," Foucault speaks of curiosity as a modality of critical thought, a modality that in its operation bears a startling resemblance to the phenomenological reduction. Through curiosity, critical thought "evokes the care one takes for what exists and what might exist" (Foucault, quoted in Rabinow 1997, xxi). With this invocation of care, Foucault reminds us of the stakes of critique, and that power is never reducible nor intimately proximate to the individual. He continues in his description of all that is called up by curiosity: "a sharpened sense of reality, but one that is never immobilized before it; a readiness to find what surrounds us strange and odd; a certain determination to throw off our familiar ways of thought and to look at the same things in a different way" (xxi). Foucault's curiosity is here twin to Eugen Fink's "wonder" before the world, a faculty that when we are able to exercise it, when we engage our "determination" to see the world anew, renders that which surrounds us as suddenly strange and odd.

The caricature of phenomenology as a philosophy that is too subjective and too trapped inside first-person perspective to be able to offer any purchase on ethical or political struggles sees its mirror opposite in the caricature of critical theory as too structurally focused, too "high-altitude," to borrow from Merleau-Ponty, to be able to offer any insight into the intimate textures of lived experience. But as I hope to at least gesture

\footnotetext{
${ }^{4}$ See also Eugen Fink's comments on wonder in "The Problem of Edmund Husserl's Phenomenology." See Bruzina, Edmund Husserl and Eugen Fink (2004, 348).
} 
toward here, neither of these formulations is sufficiently attentive to either methodology. The world is always at stake in my phenomenological perceptions. When I reach, it is into the world and toward alterity that I am reaching. And critical theory's anchor in structural considerations can be motivated by the most urgently personal of concerns.

"Untimeliness and Punctuality" (2005) is an essay by Wendy Brown in which she considers critical theory as "a hope rather than a luxury in dark times" (5). She reminds us that the first gesture of critique is not dismissal or a turning away but a moving closer with attention, care, curiosity. It can also have the effect of disorienting us, if exactly by showing us how much is at stake in our considerations, including ourselves. But disorientation is not its primary result. Critical theory, Brown says, is necessarily attuned to its times and engaged with politics, but it cannot be merely negation. It is "bound not only to speak to the times but also to affirm them...critical theory focused on political life is not negation, destruction, or nihilism; rather, critical theory aims to render crisis into knowledge, and to orient us in the darkness. Critique that does not affirm life, affirm value, and above all affirm possibilities in the present and the future, while certainly possible, is not making a bid for political power and hence cannot be understood as political" (15). ${ }^{5}$ Thus, even in its most political moments, critique is necessarily a project of affirmation and even of "reclamation," in Brown's words. It is a setting-right of the wrongs perpetrated by failures of justice, but a setting-right that may proceed in ways that are untimely, a cycle of rupture and repair whose temporality is unsettled by the force of critique.

Returning to the question that centrally concerns this paper: when asking what a critical phenomenology is, we might maintain that it reflects on the structural conditions of its own emergence, and in this it is following an imperative that is both critical in its reflexivity and phenomenological in its taking-up of the imperative to describe what it sees in order to see it anew. In this, what is critical about critical phenomenology turns out to have been there all along.

A familiar trope in literary studies today is the characterization of critique as a way of thinking whose time has passed, and critical theory as a paranoid style of reading that has exhausted itself. In The Limits of Critique (2005), Rita Felski, for instance, understands critique as synonymous with suspicion, paranoia, and negation, and has asserted that after decades of critique, we are living in a postcritical age, one in which criticism has spent itself, and new modes of reading must be found. The most paradoxical thing about this way of describing critique - and Felski's book here joins Eve Sedgwick's writing in Touching Feeling: Affect, Pedagogy, Performativity (2003) on paranoid and reparative reading - is that even as it makes a strident and even moral call for a different kind of reading practice, it itself proceeds by assessing its object and finding it suspicious, bankrupt, duplicitous. That is: when it grounds its demand for the abandonment of critique in a diagnosis of critique as suspicious, paranoid, skeptical, and asymmetrical, such a work shows itself to be more "critical" than the critical theory it lampoons. What seems to elude the practitioners of these attacks on critique is that these attacks are comprised of nothing other than criticism, and criticism of a very particular kind, one well-captured by Penelope Deutscher's observation of "that interesting gesture of wanting what can't be supplied

${ }^{5}$ I thank A.B. Huber for reminding me of this passage. 
from a theory understood as having failed to provide it" $(2017,6)$. But not all critiques of critique are quite so cartoonish. Indeed, not all calls for new reading practices within literary studies understand these practices to be opposed to critique; some proponents of "surface reading," for instance, understand such modes of reading to themselves be forms of critical practice, ones that proceed by way of description. ${ }^{6}$

Moving to dismiss critique on the grounds that it has outlived its usefulness requires one to overlook a vast swath of current work in critical theory engaged with questions of violence, racial injustice, gender inequality, and a host of other urgent political issues. ${ }^{7}$ Critical theory, in the broadest sense, offers a supplement to phenomenology in particular and to philosophy in general through its engagement with matters such as these, which philosophy has too often dismissed as to the side of "real" philosophical concerns. What future promise might be offered by the intertwining of these two apparently "outmoded" styles of thought, phenomenology and critique? We can have a better sense of an answer if we return to the question of what critique can do, a question that Judith Butler has repeatedly taken up.

Butler asks "whether a passage through a transcendental form of argumentation can lead to political and social consequence" when thinking about critique, noting its origin in Kant and the transformations it undergoes when taken up by Foucault to think about power, knowledge, and the subject $(2009,776)$. Butler reminds us that for Kant, critique is a way of calling into question the self-legitimation of philosophy, and that critique operates with two questions that light the way toward inquiry: in what way and by what right? Through Kant and Foucault, she defines critique as "the operation that seeks to understand how delimited conditions form the basis for the legitimate use of reason in order to determine what can be known, what must be done, and what may be hopedthe three aims of critique as Kant formulated them" (787). Critique, for Foucault, is ultimately indistinguishable from the production of the self. Here we would seem to be at a far distance indeed from the comparatively more pedestrian aims of phenomenological description. And yet, beneath the determination of delimited conditions, beyond the epistemological limit-seeking often understood to comprise critique, Butler finds at its heart an openness: "The notion of critique is bound up with what we still call open inquiry, even though we understand that what makes an inquiry open is something that circumscribes and binds the inquiry and so determines a limit to its operation" (776).

Utilizing Merleau-Pontian phenomenology and critique together is not without its dangers. There are plenty of points at which the two methods appear as divergent, if not incompossible, and there may be some perversity on insisting on the possibility of their pairing. When, in the preface of the Phenomenology of Perception, Merleau-Ponty speaks of truth and error, he does so with the cheerful confidence that in our experience of the world, we are already apprehending truth. "We are in the truth," he writes, "and evidentness is "the experience of truth"" (2012, xxx). When we are asking after the nature of our perceptions, or the essence of perception itself, we are not contending that this or that perception is true, "but rather that perception is defined as our access to the

\footnotetext{
${ }^{6}$ See Stephen Best and Sharon Marcus, "Surface Reading" (2009); Love, "Close but not Deep: Descriptive Ethics and the Literary Turn" (2010) and "Close Reading and Thin Description" (2013); and Best, Marcus, and Love, "Building a Better Description” (2016).

${ }^{7}$ Exemplary of the abundance of such work within contemporary critical theory is Amy Allen's series "New Directions in Critical Theory" with Columbia University Press and the series "Reinventing Critical Theory," edited by Gabriel Rockhill and Yannik Thiem with Rowman and Littlefield.
} 
truth" (xxx). This smacks of the presentism of which phenomenology is often accused, and would seem to orient phenomenology in opposition to critique, which might ask how that truth came to be true in the first place, what structures of power undergird and what forms of knowledge secure its legitimation. Is Merleau-Ponty advocating a form of naiveté in which anything I perceive must be true? Does not this kind of epistemological privilege assume a subject that is not being imperiled or crushed by the "truth" that he or she stands before? These are fair questions, and ones that may not be fully satisfied with the resources that classical phenomenology has to offer.

Looking at critique with careful eyes, however, leads us to three fundamentally significant resonances with the critical and phenomenological enterprises. First is the suggestion that critique, like phenomenology, is an attempt to move beyond a kind of dualism, a "move beyond the outside-inside alternative" (Foucault 1997, 315) in order to push into "the frontiers" of what is known. Second is the insistence that what at first appears to be a purely negative endeavor, a finding of limit, is incomplete if, upon finding that limit, it comes to a stop. Just as the reduction is not a means to banish or negate the world, but rather the condition through which it can more fully emerge, critique is not a cataloguing of the limitations of the present situation, as Wendy Brown reminds us. "We are not talking about a gesture of rejection," Foucault states firmly, in a refutation of those characterizations of critique that view it as merely negation, unproductive, sterile (315). The critique that Foucault calls for transforms its questions into a positive mode. As he describes it:

$[1] \mathrm{f}$ the Kantian question was that of knowing [savoir] what limits knowledge [connaissance] must renounce exceeding, it seems to me that the critical question today must be turned back into a positive one: In what is given to us as universal, necessary, obligatory, what place is occupied by whatever is singular, contingent, and the product of arbitrary constraints? The point, in brief, is to transform the critique conducted in the form of necessary limitation into a practical critique that takes the form of a possible crossing-over [franchissement]. (315)

And it is in that crossing-over, that gesture of opening, where the phenomenological and critical projects find what is arguably their strongest resonance. Surprisingly enough, for critique - just as for phenomenology - that opening is revealed through the work of description. To read critique as an unmasking, or the paranoid excavation of what is "really" going on behind superficial appearances, is to altogether mistake the relation between the apparent and the real. As Foucault puts it: "the role of philosophy is not to discover what is hidden, but to make visible precisely what is visible, that is to say, to make evident what is so close, so immediate, so intimately linked to us, that because of that we do not perceive it. Whereas the role of science is to reveal what we do not see, the role of philosophy is to let us see what we see" (Foucault, quoted in Davidson 1997, 2). ${ }^{8}$ For all Foucault's resistance to phenomenology, the centrality of this fundamental phenomenological insight to his own method is manifest and significant.

\footnotetext{
${ }^{8}$ Davidson cites Foucault's "La Philosophie analytique de la politique," part of his untranslated Dits et écrits (1978). Davidson hears in this passage a "tone reminiscent of Wittgenstein, but without mentioning his name" (1997, 2); I myself, perhaps not unsurprisingly, hear an echo of Merleau-Ponty's language in this passage.
} 
Foucault's view of truth, like Merleau-Ponty's, is resolutely non-idealist. When he states that "[truth is a thing of this world," he is, like Merleau-Ponty, insisting that truth is not hidden (Foucault 1980, 131). But truth for Foucault cannot be thought without attending to the constraints that produce it. That truth is of this world means that it is not ideal or transcendental, but also, crucially, that it is always saturated with power relations: "Truth isn't outside power, or lacking in power" (131). It is here that the joining of the critical and the phenomenological might be most urgent: if phenomenology offers us unparalleled means to describe what we see with utmost precision, to illuminate what is true, critique insists that we also attend to the power that is always conditioning that truth.

Notwithstanding the parsing of these categories, what can we say about works that might be counted as critical phenomenology, or that name themselves thusly? How might a newly enlivened kind of scholarship emerge from these two forms of thinking, both of which have been dismissed as outmoded or irrelevant? Guenther, you will recall, names Fanon, Merleau-Ponty, and Levinas as her primary interlocutors. She even dubs them as "postphenomenologists," as a way of naming their critical potential, despite the fact that they all reside uncontroversially within the phenomenological tradition, thus ensuring that the relationship between phenomenology and critical phenomenology is not one of inside and outside, but perhaps of crossing over, where each lends its insights to the other. Sara Ahmed's Queer Phenomenology: Orientations, Objects, Others (2006) uses the spatial orientations of phenomenology to think about queerness, and also uses queer reading practices to reexamine phenomenology's own presuppositions. Or we might think of Johanna Oksala's (2016) recent work, in which she combines phenomenology and Foucauldian critical theory to rethink the relations among feminism, ontology, and relations of power. Or, still more expansively, the phenomenology of listening offered by Jill Stauffer's Ethical Loneliness: The Injustice of Not Being Heard (2015), in which she uses Levinas to teach us to re-hear the testimony of survivors of violence and traumatic injustice. How can we use phenomenology to think about the urgent dilemmas of our present moment, including those subjects that phenomenology itself failed to adequately address? To my mind, Amy Allen's book The End of Progress: Decolonizing the Normative Foundations of Critical Theory (2016) is a model of theoretical work that uses the conceptual tools and frameworks within critical theory to challenge its own complicity in perpetuating unjust structures of power and inequality. ${ }^{9}$ And Allen, too, invokes the power of openness, using it to name a kind of epistemic humility that is required for the decolonization of critical theory. She calls for an open-ended dialogue with alterity within critical theory and proposes that "such an openness and open-endedness require what Chakrabarty characterizes as an openness 'to the possibility of our thought systems ... being rendered finite by the presence of the other" (210). The new work currently emerging in phenomenology offers every reason to hope that it, too, might be on the cusp of its own decolonization and reflexive self-consideration, and that it might yet be capacious enough to simultaneously encompass the revelation of its limitations as well as the expansion of its reach.

Describing the reaction of readers encountering phenomenology for the first time, Merleau-Ponty says that many philosophers upon encountering it did not exactly have the experience of coming up on a new philosophy, but rather of finding a thing for

\footnotetext{
${ }^{9}$ See in particular Amy Allen's discussion of Adorno, Foucault, and the postcolonial in The End of Progress (2016, 198-203).
} 
which they had long been waiting (2012, xxi). It is an essential rather than an accidental feature of phenomenology that it constantly renews itself in a deliberately suspended state between a present, intimate expression and the open field in which all of its notyet-arrived and unpredictable iterations will emerge, inexhaustibly. If it is true that, as Merleau-Ponty said, "phenomenology has remained for so long in a nascent state, as a problem and as a promise," then surely this is no less true presently for critical phenomenology (xxi). If phenomenology is still a problem and a promise, this sets before the budding critical phenomenologist a task less taxonomical than speculative, that in viewing the world and describing it with all possible precision, we might see the world and all the objects and others within it open, and reveal themselves to be more varied and more mysterious than our imaginations could have conjured, or our schemas of knowledge contain. And we can reflexively consider our own philosophical legacies, including their omissions and their missteps, not to dismiss those older forms of thinking and ways of understanding but to constantly renew them and expand their capacities.

Openness, Merleau-Ponty says, is the problem he was immersed in when working on The Visible and the Invisible (1968). It is the problem that would occupy him through the writing of that unfinished work, the problem that was shared with dialectics and Marxism. The problem and the promise of openness may still be the source from which phenomenology's richest possibilities spring forth, even in these dark times.

\section{REFERENCES}

Ahmed, Sara. 2006. Queer Phenomenology: Orientations, Objects, Others. Durham: Duke University Press.

Allen, Amy. 2016. The End of Progress: Decolonizing the Normative Foundations of Critical Theory. New York: Columbia University Press.

Best, Stephen and Sharon Marcus. 2009. "Surface Reading: An Introduction." Representations 108(1): 1-21.

Brown, Wendy. 2005. Edgework: Critical Essays on Knowledge and Politics. Princeton: Princeton University Press.

Bruzina, Ronald. 2004. Edmund Husserl and Eugen Fink: Beginnings and Ends in Phenomenology, 1928-1938. New Haven: Yale University Press.

Butler, Judith. 2009. "Critique, Dissent, Disciplinarity." Critical Inquiry 35(4): 773-795.

Carr, David. 1973. "The 'Fifth Meditation' and Husserl's Cartesianism." Philosophy and Phenomenological Research 34(1): 14-35.

Davidson, Arnold I. 1997. "Structures and Strategies of Discourse: Remarks Toward a History of Foucault's Philosophy of Language." Foucault and his Interlocutors. Edited by Davidson I. Arnold, 1-20. Chicago: The University of Chicago Press.

Deutscher, Penelope. 2017. Foucault's Futures: A Critique of Reproductive Reason. New York: Columbia University Press.

Felski, Rita. 2005. The Limits of Critique. Chicago: The University of Chicago Press. Fink, Eugen. 1981. "The Problem of Edmund Husserl's Phenomenology." In Apriori and World: European Contributions to Husserlian Phenomenology, edited and translated by William McKenna, Robert M. Harlan, and Laurence E. Winters, 21-55. The Hague: Martinus Nijhoff Publishers. 
Foucault, Michel. 1997. "What is Enlightenment." In Ethics, Subjectivity and Truth, (Essential Works of Foucault, 1954-1984, Vol. 1), edited by Paul Rabinow. Translated by Robert Hurley and others, 303-320. New York: The New Press.

- 1980. "Truth and Power." Power/Knowledge: Selected Interviews and Other Writings, 1972-1977. Edited by Colin Gordon, 63-77. New York: Pantheon.

Guenther, Lisa. 2013. Solitary Confinement: Social Death and its Afterlives. Minneapolis: University of Minnesota Press.

Irigaray, Luce. 1993. An Ethics of Sexual Difference, translated by Carolyn Burke and Gillian C. Gill. Ithaca: Cornell University Press.

Larison, Mariana. 2016. L'être en forme. Dialectique et phénomenologie dans la dernière philosophie de Merleau-Ponty. Éditions Mimésis.

Love, Heather. 2010. "Close but not Deep: Descriptive Ethics and the Literary Turn." New Literary History 41(2): 371-391.

- 2013. "Close Reading and Thin Description." Public Culture 25(3 (71)): 401-434.

Marcus, Sharon, Heather Love, and Stephen Best. 2016. "Building a Better Description." Representations 135(1): 1-21.

Marder, Michael. 2014. Phenomena-critique-logos: The Project of Critical Phenomenology. London: Rowman and Littlefield.

Marratto, Scott. 2017. "Alterity and Expression in Merleau-Ponty: A Response to Levinas." In Perception and its Development in Merleau-Ponty's 'Phenomenology,' edited by Kirsten Jacobson and John Russon, 242-250. Toronto: University of Toronto Press.

Merleau-Ponty, Maurice. 2012. Phenomenology of Perception, translated by Donald Landes. New York: Routledge.

- 1968. The Visible and the Invisible, edited by Claude Lefort. Translated by Alfanso Lingis. Evanston: Northwestern University Press.

—. nd [1959?]. "Unpublished Note." Bibliothèque Nationale de France VIII.2. - 1964. "The Philosopher and his Shadow." Signs, 159-181. Translated by Richard C. McCleary. Evanston: Northwestern University Press.

Morris, David. 2017. "Merleau-Ponty and Mexica Ontology: Time as Templace ment." Paper presented at the International Merleau-Ponty Circle, Albuquerque, NM, November 4, 2017.

Oksala, Johanna. 2016. Feminist Experiences: Foucauldian and Phenomenological Investigations. Evanston: Northwestern University Press.

Rabinow, Paul. 1997. "Introduction: The History of Systems of Thought." In Ethics: Subjectivity and Truth (The Essential Works of Foucault, 1954-1984, Vol. 1), edited by Paul Rabinow, xi-xlii. New York: The New Press.

Sedgwick, Eve. 2003. "Paranoid Reading and Reparative Reading." Touching Feeling: Affect, Pedagogy, Performativity, 123-152. Durham: Duke University Press.

Stauffer, Jill. 2015. Ethical Loneliness: The Injustice of Not Being Heard. New York: Columbia University Press.

Velmans, Max. 2007. "Heterophenomenology versus Critical Phenomenology." Phenomenology and the Cognitive Sciences 6(1-2): 221-230.

Welton, Donn. 1987. "Introduction." In Critical and Dialectical Phenomenology, edited by Donn Welton and Hugh Silverman, xi-xxiii. Albany: SUNY University Press. 